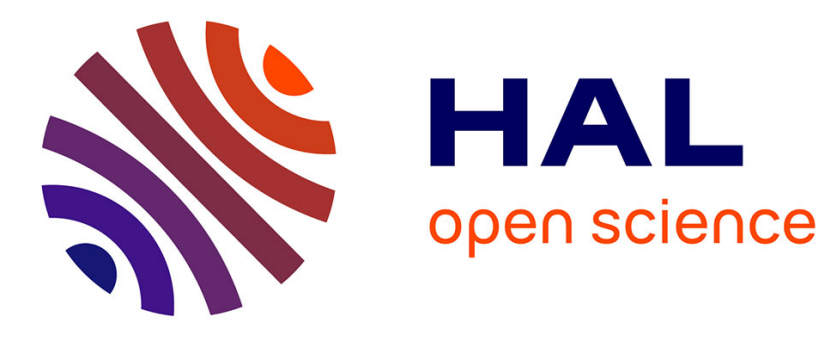

\title{
Gold/Polyoxometalate Core/Shell Nanoparticles for Combined Chemotherapy-Photothermal Cancer Therapy
}

Somia Tomane, Claire Wilhelm, Souhir Boujday, Alexandre Fromain, Antoine Miche, Flavien Bourdreux, Anne Dolbecq, Pierre Mialane, Anne Vallée

\section{- To cite this version:}

Somia Tomane, Claire Wilhelm, Souhir Boujday, Alexandre Fromain, Antoine Miche, et al.. Gold/Polyoxometalate Core/Shell Nanoparticles for Combined Chemotherapy-Photothermal Cancer Therapy. ACS Applied Nano Materials, 2021, 4 (3), pp.2339-2344. 10.1021/acsanm.0c03187 . hal-03214106

\section{HAL Id: hal-03214106 https://hal.science/hal-03214106}

Submitted on 27 May 2021

HAL is a multi-disciplinary open access archive for the deposit and dissemination of scientific research documents, whether they are published or not. The documents may come from teaching and research institutions in France or abroad, or from public or private research centers.
L'archive ouverte pluridisciplinaire HAL, est destinée au dépôt et à la diffusion de documents scientifiques de niveau recherche, publiés ou non, émanant des établissements d'enseignement et de recherche français ou étrangers, des laboratoires publics ou privés. 


\section{Gold/Polyoxometalate Core/Shell Nanoparticles for}

\section{Combined Chemo-Photothermal Cancer Therapy}

Somia Tomane, ${ }^{\mathrm{a}, \mathrm{b}}$ Claire Wilhelm, ${ }^{\mathrm{c}, \mathrm{d}}$ Souhir Boujday, ${ }^{\mathrm{b}}$ Alexandre Fromain, ${ }^{\mathrm{c}, \mathrm{d}}$ Antoine Miche ${ }^{\mathrm{b}}$, Flavien Bourdreux, ${ }^{\mathrm{a}}$ Anne Dolbecq, ${ }^{\mathrm{a}}$ Pierre Mialane ${ }^{\mathrm{a}}$ and Anne Vallée*a

a Institut Lavoisier de Versailles, UMR CNRS 8180, UVSQ, Université Paris-Saclay, 45, avenue des Etats-Unis, 78035 Versailles Cedex, France. E-mail : anne.vallee@uvsq.fr

${ }^{\mathrm{b}}$ Sorbonne Université, Laboratoire de Réactivité de Surface (LRS), UMR CNRS 7197, 4 place Jussieu, 75252 Paris, France.

${ }^{\mathrm{c}}$ Laboratoire Matière et Systèmes Complexes (MSC), UMR CNRS 7057, Université de Paris, 75013 Paris, France.

d Institut Curie, Université PSL, Sorbonne Université, CNRS UMR168, Laboratoire Physico Chimie Curie, 75005 Paris, France.

KEYWORDS Core/shell nanoparticles, Gold nanoparticles, Polyoxometalate, Hyperthermia, Cancer treatment 


\section{ABSTRACT}

We designed monodisperse and perfectly shaped core/shell AuNP@ $\mathrm{Mo}_{4} \mathrm{Zol}_{2} \mathrm{Mn}$ nanohybrids consisting of gold nanoparticles functionalized by an antitumoral polyoxometalate incorporating the biologically active zoledronate ligand. After incubation, the nanoparticles readily confined in the endosomal compartments of PC3 human prostate adenocarcinoma cells. Under photothermal treatment, the metabolic activity drastically decreased at concentrations where the nanohybrids exhibited no anti-cancer activity in the dark, and almost all cancer cells were killed at concentrations at which zoledronate alone was totally inactive. This study evidences for the first time that gold nanoparticles capped by polyoxometalates can represent excellent candidates for combined chemo-photothermal cancer therapy.

Despite major advances in nanoparticles-mediated treatments of tumors, cancer nano-therapies still require increased efficiency with minimal side effects. To enhance the efficacy of the different modalities, a new trend consisting in combining therapies has emerged these last years. Significantly, the combination of chemotherapy and hyperthermia has shown stronger therapeutic effect compared to stand alone therapy. ${ }^{1}$ Due to their easy functionalization allowing couplings with therapeutic agents and their ability to translate absorbed light into thermal energy, gold nanoparticles (AuNPs) have been recognized as first-in-class agents in nanomedicine., Several studies have shown that the combination of drugs with gold nanoparticles improves the drug chemotherapeutic effects and is accompanied by a decrease in toxicity allowing a better accumulation within tumors in comparison to drug alone either by active or passive targeting. ${ }^{4-7}$ Besides, AuNPs show excellent performances in photothermal therapy (PTT) which are based on local light-driven heat and can be active under biological windows where the blood and tissues 
are optically transparent. ${ }^{3}$ Importantly, localized hyperthermia results in enhanced tumor accumulation and intracellular uptake of drugs because it increases the vascular permeability within the tumor and the cell membrane permeability. ${ }^{8}$ This translates into a possible decrease in drug concentration for a similar therapeutic efficacy.

Polyoxometalates (POMs) are negatively charged tunable molecular oxides based on metals in high oxidation states (typically $\mathrm{W}^{\mathrm{V}, \mathrm{VI}}, \mathrm{Mo}^{\mathrm{V}, \mathrm{VI}}$ and $\mathrm{V}^{\mathrm{IV}, \mathrm{V}}$ ) ${ }^{9,10}$ exhibiting a wide range of properties including magnetic, ${ }^{11}$ catalytic, ${ }^{12}$ optical $^{13}$ as well as biological including antibacterial ${ }^{14}$ and antitumoral $^{15}$ activities. Their intrinsic ability to inhibit tumor growth, POMs being able to penetrate cells and reach the cytoplasm, ${ }^{15}$ can be further improved due to their characteristics which make them unique with respect to material properties: a) these high-nuclearity systems can form complexes with various metal oxidation states and thus with either strong oxidative or reductive properties; b) their high negative charge allow them to readily interact with cationic entities via electrostatic interactions, and they can thus easily functionalize particles or surfaces; c) they can also be easily functionalized either by additional inorganic fragments or by organic substrates, leading to synergistic effects, d) some POMs only contain metals with a low toxicity, such as molybdenum, and are thus perfectly biocompatible. For instance, the anticancer activity of POM-bisphosphonate complexes such as the $\left[\left(\mathrm{Mo}_{2}{ }_{2} \mathrm{O}_{6}\right)_{2}\left(\mathrm{O}_{3} \mathrm{PC}\left(\mathrm{C}_{4} \mathrm{H}_{6} \mathrm{~N}_{2}\right) \mathrm{OPO}_{3}\right)_{2} \mathrm{Mn}^{\mathrm{III}}\right]^{5-}$ $\left(\mathrm{Mo}_{4} \mathrm{Zol}_{2} \mathrm{Mn}\right.$, with $\left.\mathrm{Zol}=\left[\mathrm{O}_{3} \mathrm{PC}\left(\mathrm{C}_{4} \mathrm{H}_{6} \mathrm{~N}_{2}\right) \mathrm{OPO}_{3}\right]^{5-}\right)$ zoledronate POM was found to exhibit high antitumoral activity against human breast adenocarcinoma MCF-7 cell line ${ }^{16}$ and human nonsmall cell lung cancer NCI-H460 cells in vitro, and against SK-ES-1 sarcoma tumor cells growth in vivo. ${ }^{17}$ Within $\mathrm{Mo}_{4} \mathrm{Zol}_{2} \mathrm{Mn}$, two deprotonated zoledronic acid molecules, a drug $\left(\right.$ Zometa $\left.{ }^{\circledR}\right)$ used to treat osteoporosis but also known to exhibit direct and indirect antitumoral effects against a broad variety of tumor cell lines, are connected to an inorganic $\left\{\mathrm{Mo}^{\mathrm{VI}}{ }_{4} \mathrm{Mn}^{\mathrm{III}}\right\}$ 
core (Figure S1) ${ }^{18,19}$ Importantly, the antitumoral activity of the zoledronate POM, expressed per zoledronate unit, was much higher than that of the zoledronate alone for all the POM's compositions, as the result of a synergistic effect between the inorganic POM core and the bisphosphonate. Besides, it has been demonstrated that POMs can be used as protecting ligands of metallic nanoparticles, including $\mathrm{Ag}, \mathrm{Pt}, \mathrm{Pd}$ and $\mathrm{Au} \mathrm{NPs} .{ }^{20}$ In particular, they can play a significant role in the synthesis and the stabilization of Au NPs and also promote applications in numerous fields such as catalysis, biosensing and medicinal use ${ }^{21}$ through their surface functionalization. For example, antibacterial activities of AuNPs functionalized with Keggintype $\mathrm{POMs}^{22}$ or polyoxovanadate bisphosphonate molecules ${ }^{23}$ as well as cytotoxic effects of AuNP@POM $\left(\mathrm{POM}=\left[\mathrm{Na}\left\{\left(\mathrm{Mo}_{2}{ }_{2} \mathrm{O}_{4}\right)_{3} \mathrm{O}_{3}\left(\mathrm{SO}_{3}\right)_{4}\right\}_{2}\right]^{15}\right)$ in $\mathrm{B} 16$ (mouse melanoma) cell lines ${ }^{24}$ have been reported.

In what follows, we intended to combine the multiple features described above by designing and fully characterizing a new nanohybrid based on AuNPs functionalized with $\mathrm{Mo}_{4} \mathrm{Zol}_{2} \mathrm{Mn}$ POMs. The biostability of the resulting AuNP@ $\mathrm{Mo}_{4} \mathrm{Zol}_{2} \mathrm{Mn}$ was evidenced in culture media, and the anticancer activity of this nanohybrid against PC3 human prostate adenocarcinoma cells was then investigated in the dark and under irradiation (Scheme 1). To the best of our knowledge, this work represents the first study devoted to combined chemo-photothermal therapy using a NP@POM nanosystem.

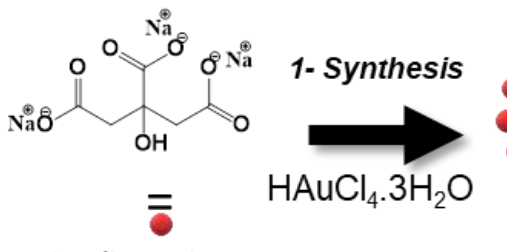

Trisodium citrate

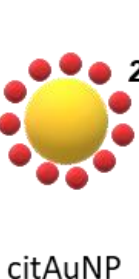

citAuNP
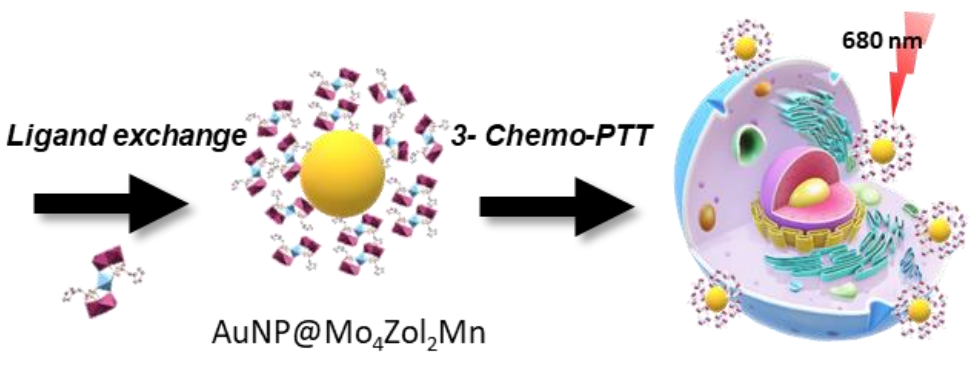
Scheme 1. Schematic representation of the AuNP@ $@ \mathrm{Mo}_{4} \mathrm{Zol}_{2} \mathrm{Mn}$ synthetic pathway and chemophotothermal application.

The synthesis of AuNP@Mo $\mathrm{Mol}_{4} \mathrm{Znn}$ consists of two steps. Spherical AuNPs were prepared using citrate ions as reducing agents and stabilizers (citAuNP) according to the Turkevich method. ${ }^{25}$ The citrate anions were then exchanged with $\mathrm{Mo}_{4} \mathrm{Zol}_{2} \mathrm{Mn}$ (Scheme 1), as reported previously for the synthesis of AuNP functionalized with Keggin ${ }^{26}$ or polyoxovanadate anions. ${ }^{23}$ The excess of POM was removed by appropriate washing, affording the targeted AuNP@Mo4Zol $2 \mathrm{Mn}$ nanohybrid. Figure 1a shows the UV-vis spectra of citAuNP and AuNP@Mo $\mathrm{Mol}_{2} \mathrm{Mn}$. The colloidal suspension of citAuNP exhibited a red color (Figure 1a, inset) with a localized surface plasmon resonance (LSPR) band located at $520 \mathrm{~nm}$ typical of spherical citrate nanoparticles. After their functionalization with $\mathrm{Mo}_{4} \mathrm{Zol}_{2} \mathrm{Mn}$, the NP LSPR band was slightly red-shifted to $528 \mathrm{~nm}$ as it has been already observed when citrates are exchanged with POMs on NPs. This has been interpreted in terms of stronger POM-NP interactions compared to citrate-NP ones. ${ }^{27}$
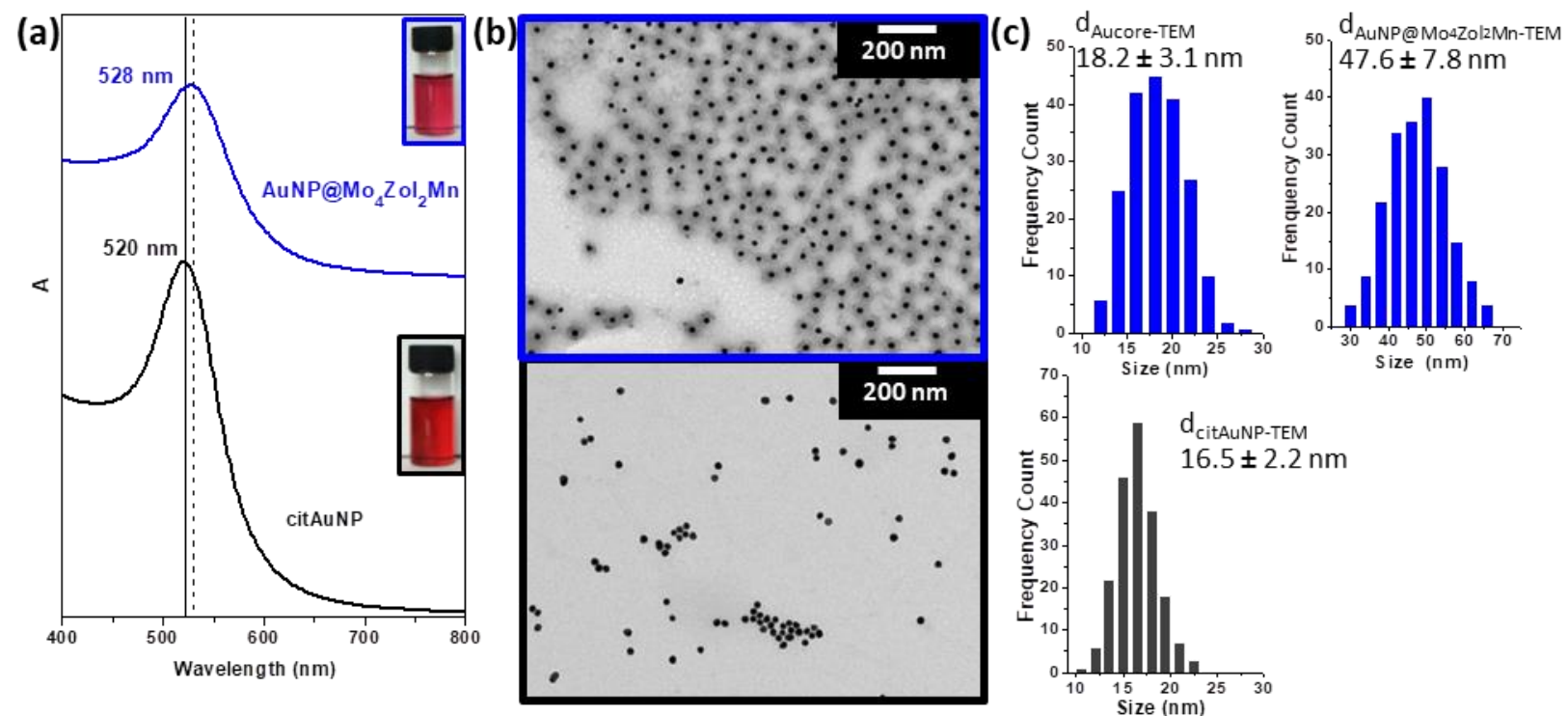
Figure 1. Characterization of citAuNP and AuNP@ $\mathrm{Mo}_{4} \mathrm{Zol}{ }_{2} \mathrm{Mn}$ : (a) UV-vis spectra and (inset) colloidal suspension pictures; (b) TEM images of citAuNP (bottom) and AuNP@Mo $\mathrm{Mo}_{4} \mathrm{Zol}_{2} \mathrm{Mn}$ (top) (c) related particle size distribution histograms.

Dynamic light scattering (DLS) experiments performed on citAuNP and AuNP@ $\mathrm{Mo}_{4} \mathrm{Zol}_{2} \mathrm{Mn}$ indicated monomodal dispersions with hydrodynamic diameters of $22.6 \pm 0.2$ and $72.8 \pm 2.5 \mathrm{~nm}$ and mean zeta potentials of $-41.1 \pm 1.2$ and $-26.6 \pm 1.4 \mathrm{mV}$, respectively (Table S1). The zeta potential increase after the ligand exchange with $\mathrm{Mo}_{4} \mathrm{Zol}_{2} \mathrm{Mn}$ can be surprising in view of the high negative charge of the POM but can be explained by the presence of sodium and ammonium counterions (see below) which significantly compensate the negative charge of the functionalized NPs. The measured AuNP@ $@ \mathrm{Mo}_{4} \mathrm{Zol}{ }_{2} \mathrm{Mn}$ negative charge is however sufficient to maintain a good colloidal stability. Transmission Electron Microscopy (TEM) images showed the morphologies and distributions of citAuNP and AuNP@ $\mathrm{Mo}_{4} \mathrm{Zol}_{2} \mathrm{Mn}$ (Figures 1b,c and S2). After their functionalization with $\mathrm{Mo}_{4} \mathrm{Zol}_{2} \mathrm{Mn}$, the spherical citAuNP with an initial average size of $16.5 \pm 2.2 \mathrm{~nm}$ exhibited a uniform well-defined core/shell structure with an Au core average size of $18.2 \pm 3.1$ and $\mathrm{AuNP} @ \mathrm{Mo}_{4} \mathrm{Zol}_{2} \mathrm{Mn}$ core/shell structure of $47.6 \pm 7.8 \mathrm{~nm}$ diameters. Notably, the formation of a shell around the AuNPs observed by TEM after POM functionalization is consistent with the shift of the LSPR band and the increased hydrodynamic diameter observed by DLS. As expected, the hydrodynamic diameter measured by DLS is larger than the one measured by TEM as it takes into account the presence of hydration layers.

Scanning Transmission Electron Microscopy 2D atomic resolution chemical mapping (STEMXEDS) evidenced the core/shell structure of AuNP@Mo $\mathrm{Mo}_{4} \mathrm{Zol} 2 \mathrm{Mn}$, with the characteristic elements (Mo, Mn, P) of $\mathrm{Mo}_{4} \mathrm{Zol}_{2} \mathrm{Mn}$ surrounding the gold core, and with the presence in the shell of sodium counter-cations (Figure S3). Attenuated Total Reflectance Fourier Transform 
Infrared (ATR-FTIR) spectrum of AuNP@ $\mathrm{Mo}_{4} \mathrm{Zol}_{2} \mathrm{Mn}$ (Figure S4 and Table S2) does not exhibit any band typical of citrate but indicates the presence of $\mathrm{Mo}_{4} \mathrm{Zol}_{2} \mathrm{Mn}$ at the surface of the functionalized NPs, confirming the ligand exchange. The $\mathrm{Mo}=\mathrm{O}$ and Mo-O vibrations characteristic of the POM inorganic core are indeed observed at $997 \mathrm{~cm}^{-1}$ and $883 \mathrm{~cm}^{-1}$, respectively, and the $\mathrm{P}=\mathrm{O}$ and $\mathrm{P}-\mathrm{O}$ vibrations related to the zoledronate ligands are located at 1288 and $1047 \mathrm{~cm}^{-1}$. Additionally, the presence of a band attributed to $\mathrm{NH}_{4}{ }^{+}$cations clearly highlights the presence in the hybrid of additional counter-cations arising from the POM precursor, also compensating the negative charges of the grafted POMs and explaining the relatively low negative charge of the nanoparticles deduced from zeta potential measurements. Additionally, we investigated the potential photoreduction of the $\mathrm{Mo}_{4} \mathrm{Zol}_{2} \mathrm{Mn} \mathrm{POM}$ under 680 nm laser irradiation by running XPS analyses of AuNP@ $\mathrm{Mo}_{4} \mathrm{Zol}_{2} \mathrm{Mn}$ before and after irradiation, the results showing no changes in the Mo oxidation state (Figure S5). Inductive Coupled Plasma Optical Emission Spectroscopy (ICP-OES) also confirmed the presence in AuNP@ $@ \mathrm{Mo}_{4} \mathrm{Zol} 2 \mathrm{Mn}$ of $\mathrm{Mo}$ and $\mathrm{P}$ in the proportions expected for the $\mathrm{Mo}_{4} \mathrm{Zol}_{2} \mathrm{Mn}$ complex, with an experimental $\mathrm{P} /$ Mo ratio of $1.1 \pm 0.1$ (calculated $\mathrm{P} /$ Mo ratio $=1)$. Taken together, these measurements validate that the POM is conserved once deposited on the AuNPs. Finally, ICP-OES was also used to quantitatively determine the POM loading at the surface of the NPs. The experimental Au/Mo ratio for the functionalized spherical gold nanoparticles leads to a value of $93 \pm 8 \mathrm{POM} / \mathrm{nm}^{2}$ (see Supplementary Information for details). This value clearly indicates the presence of POM multilayers around the gold core, in agreement with the TEM observation of a well-defined POM shell with a thickness of ca. $14.2 \pm 3.2 \mathrm{~nm}$.

The photothermal properties of AuNP@ $\mathrm{Mo}_{4} \mathrm{Zol} 2 \mathrm{Mn}$ were investigated in aqueous medium. Figure S6 summarizes the heating characteristics as function of $\mathrm{Au}$ concentration. The 
temperature increase amounts to $27^{\circ} \mathrm{C}$ with $[\mathrm{Au}]=1 \mathrm{mM}$ and the light-to-heat conversion

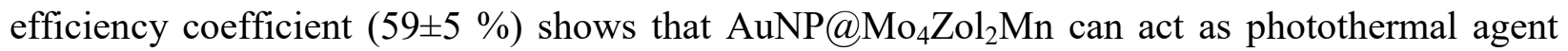
(see Supplementary Information for details).

PC3 human prostate adenocarcinoma cells were selected to evaluate the performances of AuNP@Mo $\mathrm{Mol}_{4} \mathrm{Zn}$ as antitumor agent. Before carrying out the viability tests of cancer cells in the presence of the nanohybrids, their stability in the culture media, key parameter for biological applications, ${ }^{28}$ was investigated by DLS (Figure S7). In the RPMI culture medium (RPMI = Roswell Park Memorial Institute medium) with no additives, AuNP@ $\mathrm{Mo}_{4} \mathrm{Zol}_{2} \mathrm{Mn}$ formed immediately aggregates with a diameter of $640 \mathrm{~nm}$ which increases to $1700 \mathrm{~nm}$ after $240 \mathrm{~min}$. To prevent aggregation, RPMI was supplemented with $10 \%$ of fetal bovine serum (FBS). The hydrodynamic diameter of the hybrids was then stable, around $130 \mathrm{~nm}$, over the duration of the experiment $(250 \mathrm{~min})$. The diameter increase of the nanohybrids in the biological medium compared to the one of $72.8 \mathrm{~nm}$ in water reflects the formation of protein corona stabilizing the nanoparticles. Human PC3 cells were thus incubated in RPMI supplemented with serum for 24 hours at different extracellular concentrations in zoledronate, $\mathrm{Mo}_{4} \mathrm{Zol}{ }_{2} \mathrm{Mn}$ and AuNP@Mo $\mathrm{MZol}_{2} \mathrm{Mn}$, respectively. Alamar Blue assay was used to determine the metabolic activity (see experimental section in the Supporting Information). The resulting dose-response curves shown in Figure 2 provide the half maximal inhibitory concentration $\left(\mathrm{IC}_{50}\right)$ per zoledronate of each compound (Table 1). First, it can be observed that $\mathrm{Mo}_{4} \mathrm{Zol}_{2} \mathrm{Mn}$ is about 5.5 times more active than zoledronic acid against PC3 cells. Such increase of activity was already observed for this POM considering NCI-H460 and MCF7 cell lines after $96 \mathrm{~h}$ of incubation. ${ }^{16,17}$ However, as zoledronate is known to produce time dependent inhibition of cell proliferation, it is particularly important to underline that the increase in activity from zoledronate to $\mathrm{Mo}_{4} \mathrm{Zol}_{2} \mathrm{Mn}$ is 
observed herein even after a short period of incubation (24 h) compared to these previous works. ${ }^{29}$ Furthermore, the dose-response curves of free $\mathrm{Mo}_{4} \mathrm{Zol}_{2} \mathrm{Mn}$ and AuNP@ $\mathrm{Mo}_{4} \mathrm{Zol}_{2} \mathrm{Mn}$ overlap significantly, with an equivalent $\mathrm{IC}_{50}$ for both systems, indicating that AuNP@ $\mathrm{Mo}_{4} \mathrm{Zol}_{2} \mathrm{Mn}$ retained the high antitumor activity of $\mathrm{Mo}_{4} \mathrm{Zol}_{2} \mathrm{Mn}$. This result also confirmed that $\mathrm{Mo}_{4} \mathrm{Zol}_{2} \mathrm{Mn}$ is not altered during the adsorption process on the NPs.

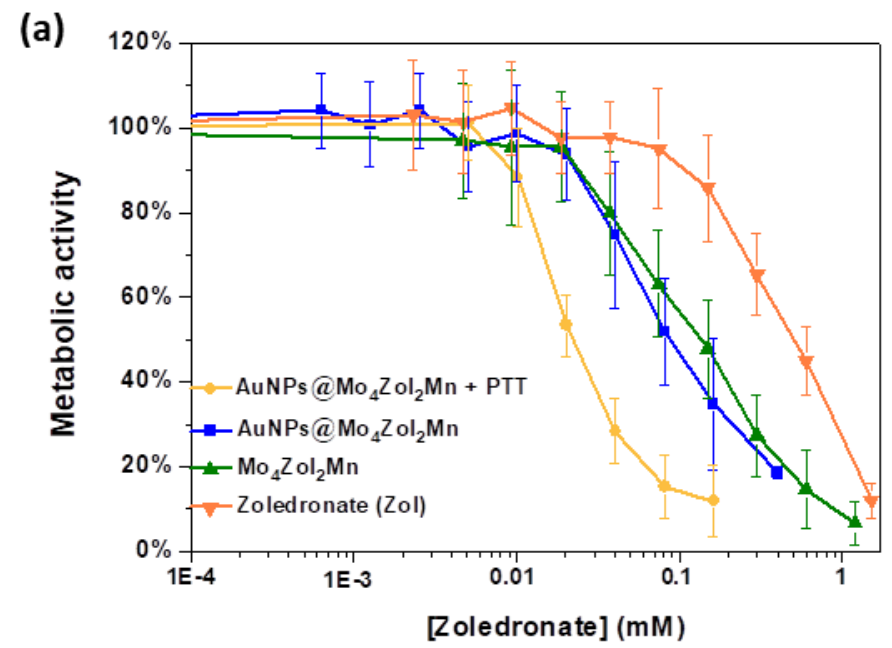

(b)

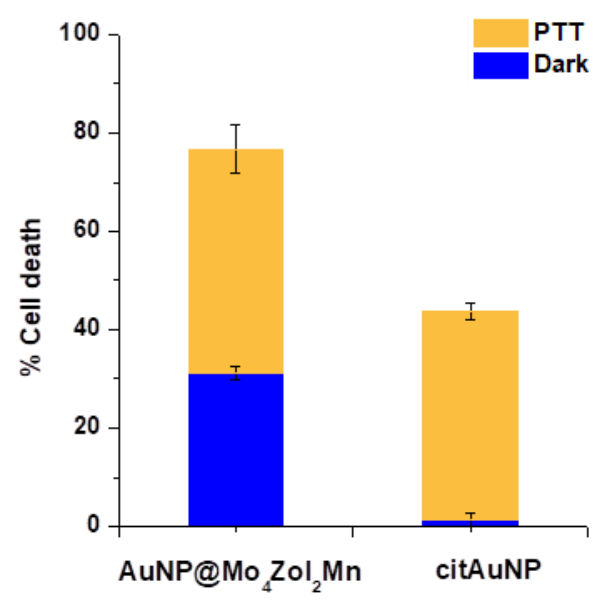

Figure 2. (a) Dose-response curves of the metabolic activity per zoledronate of PC3 cells incubated with free zoledronate (orange curve), $\mathrm{Mo}_{4} \mathrm{Zol}_{2} \mathrm{Mn}$ (green curve) and AuNP@Mo4 $\mathrm{Zol}_{2} \mathrm{Mn}$ under the presence (yellow curve, PTT) or absence (blue curve) of irradiation $(680 \mathrm{~nm})$; (b) histogram showing the contributions of citAuNP and AuNP@ $\mathrm{Mo}_{4} \mathrm{Zol}_{2} \mathrm{Mn}$ chemotherapy (blue) and PTT with irradiation $(680 \mathrm{~nm})$ induced (orange) on PC3 cells death for gold concentration of $78 \mu \mathrm{M}$.

Photothermal treatment (PTT) using a $680 \mathrm{~nm}$ laser calibrated at $1.7 \mathrm{~W} / \mathrm{cm}^{2}$ was further applied on cells incubated for $24 \mathrm{~h}$ with AuNP@ $@ \mathrm{Mo}_{4} \mathrm{Zol}_{2} \mathrm{Mn}$. At an extracellular zoledronate concentration of $20 \mu \mathrm{M}, \mathrm{Mo}_{4} \mathrm{Zol}_{2} \mathrm{Mn}$ and AuNP@Mo${ }_{4} \mathrm{Zol}_{2} \mathrm{Mn}$ exhibited no anti-cancer activity, while under irradiation at $680 \mathrm{~nm}$ in presence of AuNP@ $@ \mathrm{Mo}_{4} \mathrm{Zol}_{2} \mathrm{Mn}$ the metabolic activity 
decreased to $50 \%$. This clearly highlights a PTT effect under irradiation despite that the LSPR band of the nanohybrid is located at $528 \mathrm{~nm}$. This can be explained by the red shift of the LSPR band of nanoparticles aggregates observed on the absorbance spectrum of AuNP@Mo $\mathrm{Zol}_{2} \mathrm{Mn}$ internalized in cells and already noticed in a recent work for other gold nanosystems ${ }^{30}$ (Figure S8). Also, after irradiation in presence of the nanohybrid, the $\mathrm{IC}_{50}$ value is divided by 5 compared to the value determined for a non-irradiated AuNP@ $\mathrm{Mo}_{4} \mathrm{Zol}_{2} \mathrm{Mn}$ colloidal suspension (Table 1). This evidences gold nanoparticles PTT of AuNP@ $\mathrm{Mo}_{4} \mathrm{Zol}_{2} \mathrm{M}$.

While in presence of zoledronate at a $80 \mu \mathrm{M}$ concentration no anticancer activity was observed, the metabolic activity of PC3 cell incubated with $\mathrm{Mo}_{4} \mathrm{Zol}_{2} \mathrm{Mn}$ and AuNP@Mo $\mathrm{Mol}_{4} \mathrm{Zol}_{2} \mathrm{Mn}$ at the same zoledronate concentration decreased to $\sim 55 \%$ in the dark. Moreover, under irradiation in presence of $\mathrm{AuNP} @ \mathrm{Mo}_{4} \mathrm{Zol}{ }_{2} \mathrm{Mn}$, it decreased sharply to $\sim 15 \%$ (Figure 2a). Additionally, for a gold concentration corresponding to that of the AuNP@ $\mathrm{Mo}_{4} \mathrm{Zol}{ }_{2} \mathrm{Mn}$ sample at $80 \mu \mathrm{M}$ in zoledronate, the CitAuNPs under irradiation lead only to $\sim 40 \%$ of cell death activity of PC3 cells and to $\sim 1 \%$ without irradiation (Figure 2b). This shows that combined POM chemotherapy and photothermal therapy using AuNP@Mo $\mathrm{Zol}_{2} \mathrm{Mn}$ killed almost all cancer cells at concentrations at which pure zoledronate is inactive.

Table 1. $\mathrm{IC}_{50}{ }^{24 \mathrm{~h}}$ values per zoledronate for the studied compounds.

\begin{tabular}{|l|c|c|}
\hline Compound & $\mathrm{IC}_{50}{ }^{24 \mathrm{~h}}[\mu \mathrm{M}]$ per Zoledronate & $\mathrm{IC}_{50}{ }^{24 \mathrm{~h}}{ }_{\text {zoledronate }} / \mathrm{IC}_{50}{ }^{24 \mathrm{~h}}$ \\
\hline Zoledronate & $500 \pm 100$ & 1 \\
\hline $\mathrm{Mo}_{4} \mathrm{Zol}{ }_{2} \mathrm{Mn}$ & $140 \pm 60$ & 3.6 \\
\hline AuNP@ $\mathrm{Mo}_{4} \mathrm{Zol}_{2} \mathrm{Mn}$ & $90 \pm 30$ & 5.5 \\
\hline AuNP@Mo${ }_{4} \mathrm{Zol}{ }_{2} \mathrm{Mn}+\mathrm{PTTr}$ & $21 \pm 3$ & 23.8 \\
\hline
\end{tabular}


Additionally, TEM images of PC3 cells cultured with AuNP@Mo $\mathrm{Mo}_{4} \mathrm{Zol}_{2} \mathrm{Mn}$ at $80 \mu \mathrm{M}$ and $1 \mu \mathrm{M}$ concentrations in zoledronate are shown in Figure 3. The uptake and resulting dose of AuNP@ $@ \mathrm{Mo}_{4} \mathrm{Zol}_{2} \mathrm{Mn}$ internalized in the cells is correlated to the concentration of AuNP@Mo $\mathrm{Mol}_{2} \mathrm{Mn}$ introduced in the cells culture as it can be seen on the TEM images and the gold concentration obtained by ICP after cells washing (for AuNP@ $@ \mathrm{Mo}_{4} \mathrm{Zol}_{2} \mathrm{Mn}$ high dose $0,084 \pm 0,07 \mathrm{pg}_{\text {Au }}$ per cell and for low dose $3,64 \pm 0,5 \mathrm{pg}_{\text {Au }}$ per cell, Figure S9). These images highlight that the nanoparticles were confined in the endosomal compartments of the cells. It also demonstrates that increasing the dose leads to an increase of the number of endosomes containing the nanoparticles, but not to a marked increase of the density of the nanoparticles within the endosomes, which also appears high, whatever the dosing. It confirms the intracellular confinement of the nanohybrids and justifies the PTT activity of AuNP@ $\mathrm{Mo}_{4} \mathrm{Zol}_{2} \mathrm{Mn}$ under 680 nm irradiation.

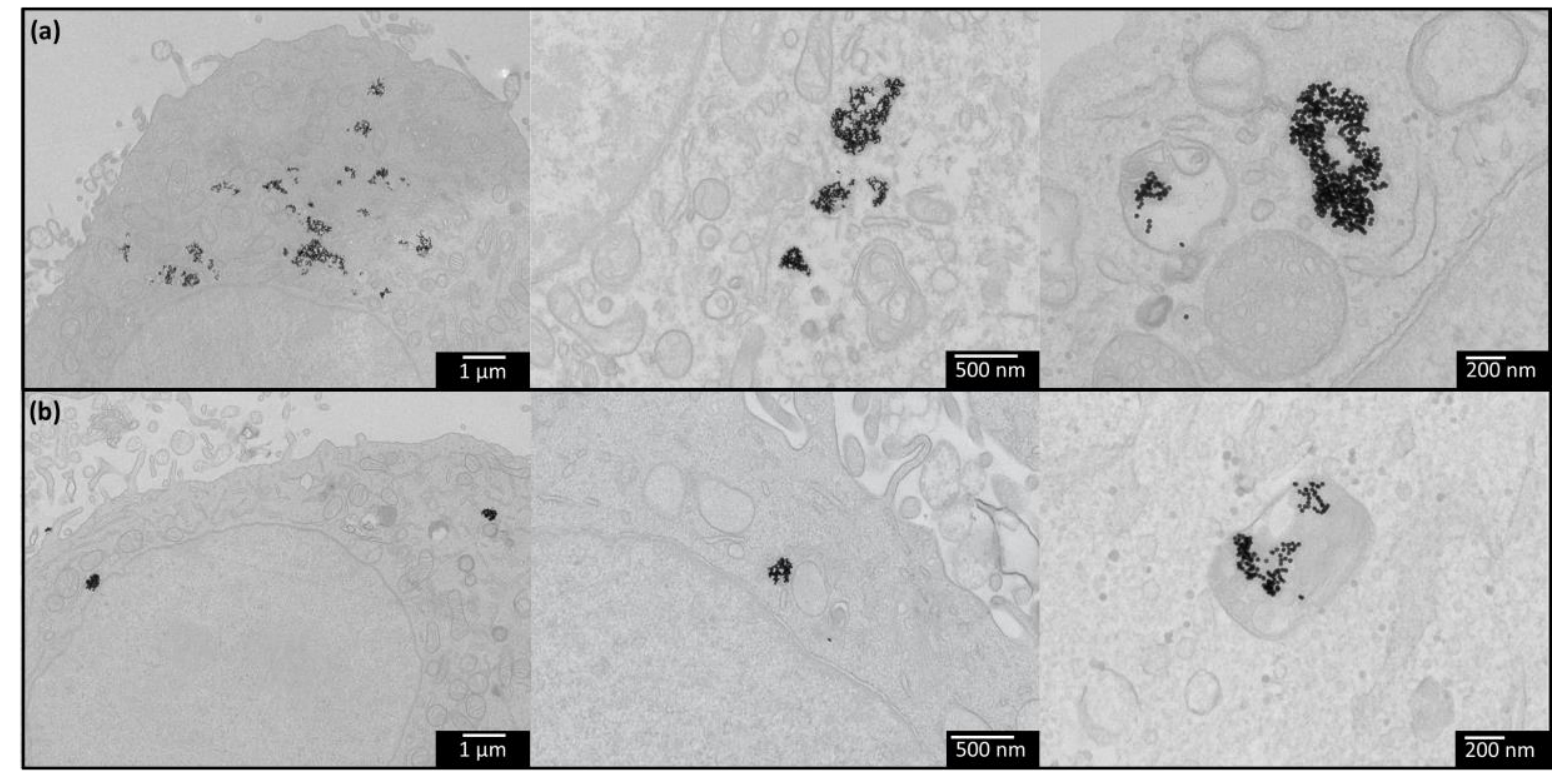

Figure 3. TEM images of AuNP@ $\mathrm{Mo}_{4} \mathrm{Zol}_{2} \mathrm{Mn}$ immediately after internalization in cancer cells for (a) $80 \mu \mathrm{M}$ and (b) $1 \mu \mathrm{M}$ in zoledronate concentrations. 
In conclusion, this work demonstrates that well defined AuNP@Mo4 $\mathrm{Zol}_{2} \mathrm{Mn}$ core/shell nanoparticles can be prepared by citrate exchange with the $\mathrm{Mo}_{4} \mathrm{Zol}_{2} \mathrm{Mn}$ antitumoral POM on preformed AuNPs. The new nanohybrids have been thoroughly characterized via TEM, DLS, UV-Vis, ATR-FTIR, ICP-OES and STEM 2D atomic resolution chemical mapping experiments. These characterizations showed that the nanohybrids form ca. $48 \mathrm{~nm}$ diameter monodispersed spherical core/shell nanostructures. The anti-cancer activity studies of AuNP@Mo $\mathrm{Mo}_{4} \mathrm{Zol}_{2} \mathrm{Mn}$ against PC3 human prostate adenocarcinoma cells evidenced that the composite is stable in a culture medium and retains the POM high antitumor activity. Photothermal treatments in the first biological window were applied on cells incubated with AuNP@ $@ \mathrm{Mo}_{4} \mathrm{Zol}_{2} \mathrm{Mn}$ and showed that at a concentration where the composite exhibited no anti-cancer activity in the dark the metabolic activity of PC3 cell decreased to 50\% under irradiation. To the best of our knowledge, this is an unprecedented demonstration that gold nanoparticles capped by polyoxometalates represent excellent candidates for combined chemo-photothermal cancer therapy. This study thus opens perspectives for the development of efficient new anti-cancer Au@POM nanomaterials, considering that organic-inorganic POMs incorporating ligands presenting antitumoral activities higher than that of zoledronate can be elaborated allowing optimizing the PTT effect. ASSOCIATED CONTENT

Supporting Information. Materials and methods, characterization techniques and additional characterization results.

\section{AUTHOR INFORMATION}

\section{Corresponding Author}

* Anne Vallée : anne.vallee@uvsq.fr 


\section{Author Contributions}

The manuscript was written through contributions of all authors. All authors have given approval to the final version of the manuscript.

\section{ACKNOWLEDGMENT}

This work was supported by the Ministère de l'Enseignement Supérieur et de la Recherche, the

CNRS, the Université de Versailles Saint Quentin en Yvelines and public grants overseen by the French National Research Agency (ANR) as part of the "Investissements d'Avenir" program no. ANR-11-IDEX-0003-02 and CHARMMMAT ANR-11-LABX-0039 and “ANR JCJC” ANR-20CE09-00001-01. C. W. also thanks the support of "Institut Pierre-Gilles de Gennes" laboratoire d'excellence, "Investissements d'avenir" program ANR-10-IDEX-0001-02 PSL and ANR-10LABX-31.

\section{REFERENCES}

(1) Wust, P.; Hildebrandt, B.; Sreenivasa, G.; Rau, B.; Gellermann, J.; Riess, H.; Felix, R.; Schlag, P. Hyperthermia in Combined Treatment of Cancer. Lancet Oncol. 2002, 3 (8), 487-497. https://doi.org/10.1016/S1470-2045(02)00818-5.

(2) Beik, J.; Khateri, M.; Khosravi, Z.; Kamrava, S. K.; Kooranifar, S.; Ghaznavi, H.; Shakeri-Zadeh, A. Gold Nanoparticles in Combinatorial Cancer Therapy Strategies. Coord. Chem. Rev. 2019, 387, 299-324. https://doi.org/10.1016/j.ccr.2019.02.025.

(3) Riley, R. S.; Day, E. S. Gold Nanoparticle-Mediated Photothermal Therapy: Applications and Opportunities for Multimodal Cancer Treatment. Wiley Interdiscip. Rev. Nanomedicine Nanobiotechnology 2017, 9 (4), e1449. https://doi.org/10.1002/wnan.1449.

(4) Pu, Y.; Zhao, Y.; Zheng, P.; Li, M. Elucidating the Growth Mechanism of Plasmonic Gold 
Nanostars with Tunable Optical and Photothermal Properties. Inorg. Chem. 2018, 57 (14), 8599-8607. https://doi.org/10.1021/acs.inorgchem.8b01354.

(5) Gibson, J. D.; Khanal, B. P.; Zubarev, E. R. Paclitaxel-Functionalized Gold Nanoparticles. J. Am. Chem. Soc. 2007, No. 24, 11653-11661.

(6) Perrault, S. D.; Walkey, C.; Jennings, T.; Fischer, H. C.; Chan, W. C. W. Mediating Tumor Targeting Efficiency of Nanoparticles through Design. Nano Lett. 2009, 9 (5), 1909-1915. https://doi.org/10.1021/n1900031y.

(7) Choi, C. H. J.; Alabi, C. A.; Webster, P.; Davis, M. E. Mechanism of Active Targeting in Solid Tumors with Transferrin-Containing Gold Nanoparticles. Proc. Natl. Acad. Sci. U. S. A. 2010, 107 (3), 1235-1240. https://doi.org/10.1073/pnas.0914140107.

(8) Raeesi, V.; Chan, W. C. W. Improving Nanoparticle Diffusion through Tumor Collagen Matrix by Photo-Thermal Gold Nanorods. Nanoscale 2016, 8 (25), 12524-12530. https://doi.org/10.1039/c5nr08463f.

(9) Lauinger, S. M.; Yin, Q.; Geletii, Y. V.; Hill, C. L. Polyoxometalate Chemistry. In Advances in Inorganic Chemistry; van Eldik, R., Cronin, L., Eds.; Academic Press, 2017; pp 117-154.

(10) Dolbecq, A.; Dumas, E.; Mayer, C. R.; Mialane, P. Hybrid Organic-Inorganic Polyoxometalate Compounds: From Structural Diversity to Applications. Chem. Rev. 2010, 110 (10), 6009-6048. https://doi.org/10.1021/cr1000578.

(11) Oms, O.; Dolbecq, A.; Mialane, P. Diversity in Structures and Properties of 3dIncorporating Polyoxotungstates. Chem. Soc. Rev. 2012, 41 (22), 7497-7536. 
https://doi.org/10.1039/c2cs35148j.

(12) Wang, S. S.; Yang, G. Y. Recent Advances in Polyoxometalate-Catalyzed Reactions. Chem. Rev. 2015, 115 (11), 4893-4962. https://doi.org/10.1021/cr500390v.

(13) Ma, P.; Hu, F.; Wang, J.; Niu, J. Carboxylate Covalently Modified Polyoxometalates: From Synthesis, Structural Diversity to Applications. Coord. Chem. Rev. 2019, 378, 281309. https://doi.org/10.1016/j.ccr.2018.02.010.

(14) Bijelic, A.; Aureliano, M.; Rompel, A. The Antibacterial Activity of Polyoxometalates: Structures, Antibiotic Effects and Future Perspectives. Chem. Commun. 2018, 54 (10), 1153-1169. https://doi.org/10.1039/c7cc07549a.

(15) Bijelic, A.; Aureliano, M.; Rompel, A. Polyoxometalates as Potential Next-Generation Metallodrugs in the Combat Against Cancer. Angew. Chemie - Int. Ed. 2019, 58 (10), 2980-2999. https://doi.org/10.1002/anie.201803868.

(16) Saad, A.; Zhu, W.; Rousseau, G.; Mialane, P.; Marrot, J.; Haouas, M.; Taulelle, F.; Dessapt, R.; Serier-Brault, H.; Rivière, E.; Kubo, T.; Oldfield, E.; Dolbecq, A. Polyoxomolybdate Bisphosphonate Heterometallic Complexes: Synthesis, Structure, and Activity on a Breast Cancer Cell Line. Chem. - A Eur. J. 2015, 21 (29), 10537-10547. https://doi.org/10.1002/chem.201406565.

(17) Boulmier, A.; Feng, X.; Oms, O.; Mialane, P.; Rivière, E.; Shin, C. J.; Yao, J.; Kubo, T.; Furuta, T.; Oldfield, E.; Dolbecq, A. Anticancer Activity of PolyoxometalateBisphosphonate Complexes: Synthesis, Characterization, in Vitro and in Vivo Results. Inorg. Chem. 2017, 56 (13), 7558-7565. https://doi.org/10.1021/acs.inorgchem.7b01114. 
(18) Green, J. R. Bisphosphonates : Preclinical Review. Oncologist 2004, 9 (suppl 4), 3-13.

(19) Zekria, J.; Mansour, M.; Karim, S. M. The Anti-Tumour Effects of Zoledronic Acid. J. Bone Oncol. 2014, 3 (1), 25-35. https://doi.org/10.1016/j.jbo.2013.12.001.

(20) Wang, Y.; Weinstock, I. A. Polyoxometalate-Decorated Nanoparticles. Chem. Soc. Rev. 2012, 41 (22), 7479-7496. https://doi.org/10.1039/c2cs35126a.

(21) Jameel, U.; Zhu, M.; Chen, X.; Tong, Z. Recent Progress of Synthesis and Applications in Polyoxometalate and Nanogold Hybrid Materials. J. Mater. Sci. 2016, 51 (5), 2181-2198. https://doi.org/10.1007/s10853-015-9503-1.

(22) Daima, H. K.; Selvakannan, P. R.; Shukla, R.; Bhargava, S. K.; Bansal, V. Fine-Tuning the Antimicrobial Profile of Biocompatible Gold Nanoparticles by Sequential Surface Functionalization Using Polyoxometalates and Lysine. PLoS One 2013, 8 (10), 1-14. https://doi.org/10.1371/journal.pone.0079676.

(23) Tomane, S.; López-Maya, E.; Boujday, S.; Humblot, V.; Marrot, J.; Rabasso, N.; CastellsGil, J.; Sicard, C.; Dolbecq, A.; Mialane, P.; Vallée, A. One-Pot Synthesis of a New Generation of Hybrid Bisphosphonate Polyoxometalate Gold Nanoparticles as Antibiofilm Agents. Nanoscale Adv. 2019, 1 (9), 3400-3405. https://doi.org/10.1039/c9na00401g.

(24) Gabas, I. M.; Stepien, G.; Moros, M.; Mitchell, S. G.; Fuenteb, J. M. de la. In Vitro Cell Cytotoxicity Profile and Morphological. New J. Chem. 2016, 40, 1039-1047.

(25) Stevenson, P. C.; Turkevich, J.; Hillier. A Study of the Nucleation and Growth Processes in the Synthesis of Colloidal Gold. Discuss. Faraday. Soc. 1951, 11 (c), 55-75.

(26) Wang, Y.; Neyman, A.; Arkhangelsky, E.; Gitis, V.; Meshi, L.; Weinstock, I. A. Self- 
Assembly and Structure of Directly Imaged Inorganic-Anion Monolayers on a Gold Nanoparticle. J. Am. Chem. Soc. 2009, $131 \quad$ (47), 17412-17422. https://doi.org/10.1021/ja907815d.

(27) Lica, G. C.; Browne, K. P.; Tong, Y. Y. Interactions between Keggin-Type Lacunary Polyoxometalates and Ag Nanoparticles: A Surface-Enhanced Raman Scattering Spectroscopic Investigation. J. Clust. Sci. 2006, 17 (2), 349-359. https://doi.org/10.1007/s10876-006-0062-0.

(28) Moore, T. L.; Rodriguez-Lorenzo, L.; Hirsch, V.; Balog, S.; Urban, D.; Jud, C.; RothenRutishauser, B.; Lattuada, M.; Petri-Fink, A. Nanoparticle Colloidal Stability in Cell Culture Media and Impact on Cellular Interactions. Chem. Soc. Rev. 2015, 44 (17), 62876305. https://doi.org/10.1039/c4cs00487f.

(29) Chang, J.; Wang, W.; Zhang, H.; Hu, Y.; Yin, Z. Bisphosphonates Regulate Cell Proliferation, Apoptosis and pro-Osteoclastic Expression in MG-63 Human Osteosarcoma Cells. Oncol. Lett. 2012, 4 (2), 299-304. https://doi.org/10.3892/ol.2012.723.

(30) Plan Sangnier, A.; Van de Walle, A.; Aufaure, R.; Fradet, M.; Motte, L.; Guénin, E.; Lalatonne, Y.; Wilhelm, C. Endosomal Confinement of Gold Nanospheres, Nanorods, and Nanoraspberries Governs Their Photothermal Identity and Is Beneficial for Cancer Cell Therapy. Adv. Biosyst. 2020, 4 (4), 1900284. https://doi.org/10.1002/adbi.201900284.

\section{SYNOPSIS}

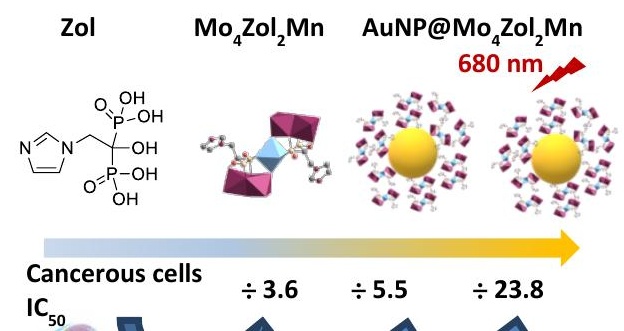


